\title{
A review of virus infections of cetaceans and the potential impact of morbilliviruses, poxviruses and papillomaviruses on host population dynamics
}

\author{
Marie-Françoise Van Bressem ${ }^{1,2, *}$, Koen Van Waerebeek ${ }^{1}$, Juan Antonio Raga ${ }^{3}$ \\ ${ }^{1}$ Peruvian Centre for Cetacean Research (CEPEC), Jorge Chávez 302, Pucusana, Lima 20, Peru \\ ${ }^{2}$ Department of Vaccinology-Immunology, Faculty of Veterinary Medicine, University of Liège, Sart Tilman, 4000 Liège, Belgium \\ ${ }^{3}$ Department of Animal Biology \& Cavanilles Research Institute of Biodiversity and Evolutionary Biology, University of Valencia, \\ Dr Moliner 50, 46100 Burjasot, Spain
}

\begin{abstract}
Viruses belonging to 9 families have been detected in cetaceans. We critically review the clinical features, pathology and epidemiology of the diseases they cause. Cetacean morbillivirus (family Paramyxoviridae) induces a serious disease with a high mortality rate and persists in several populations. It may have long-term effects on the dynamics of cetacean populations either as enzootic infection or recurrent epizootics. The latter presumably have the more profound impact due to removal of sexually mature individuals. Members of the family Poxviridae infect several species of odontocetes, resulting in ring and tattoo skin lesions. Although poxviruses apparently do not induce a high mortality, circumstancial evidence suggests they may be lethal in young animals lacking protective immunity, and thus may negatively affect net recruitment. Papillomaviruses (family Papovaviridae) cause genital warts in at least 3 species of cetaceans. In $10 \%$ of male Burmeister's porpoises Phocoena spinipinnis from Peru, lesions were sufficiently severe to at least hamper, if not impede, copulation. Members of the families Herpesviridae, Orthomyxoviridae and Rhabdoviridae were demonstrated in cetaceans suffering serious illnesses, but with the exception of a 'porpoise herpesvirus' their causative role is still tentative. Herpes-like viruses and caliciviruses (Caliciviridae) give rise to cutaneous diseases in Monodontidae and Delphinidae. Antibodies to several serotypes of caliciviruses were found in odontocetes and mysticetes. An unrecognized Hepadnaviridae was detected by serology in a captive Pacific whitesided dolphin Lagenorhynchus obliquidens with chronic persistent hepatitis. Adenoviruses (Adenoviridae) were isolated from the intestinal tracts of mysticeti and a beluga Delphinapterus leucas but were not associated with any pathologies. We discuss the potential impact of Paramyxoviridae, Poxviridae and Papovaviridae on the dynamics of several odontocete populations.
\end{abstract}

KEY WORDS: Paramyxoviridae Poxviridae Papovavinidae Herpesviridae - Orthomyxoviridae Rhabdoviridae Caliciviridae. Hepadnaviridae Adenoviridae Cetaceans - Viral diseases

\section{INTRODUCTION}

Evidence is mounting that microparasites, including viruses, bacteria, and protozoans, may constrain the growth of wild animal populations (Anderson \& May 1979, Anderson 1982, Fenner 1983, Gulland 1995). The intensity of this effect is a function of the heightened mortality rate and/or reduction in reproductive capacity. Thus, microparasites may increase the risk of

•E-mail:mariefvb@blockbuster.com.pe extinction of small populations in combination with other factors (May 1986. Thorne \& Williams 1988, Gulland 1995, Raga et al. 1997).

The potential of viruses to regulate, or slow, the growth rate of cetacean populations was mostly overlooked until the advent of morbillivirus mortalities in harbour porpoises Phocoena phocoena in the northeastern (NE) Atlantic in 1988-1990 and of a lethal epizootic of morbillivirus in striped dolphins (Stenella coeruleoalba) in the Mediterranean in 1990-1992 (Kennedy et al. 1988, Domingo et al. 1990, Van Bressem et al. 1991, 1993a). These mortalities have 
stimulated research on these and other virus infections in cetaceans and stressed the need to investigate their long-term consequences.

To date, viruses belonging to 9 families have been detected in cetaceans (Table 1). In this paper, we critically review the clinical features, pathology and epidemiology of the diseases they cause (Table 1). We discuss evidence for the potential impact of Paramyxoviridae, Poxviridae and Papovaviridae on the dynamics of several odontocete populations. Only for these virus families is there enough clinical and epidemiological information to allow such speculation.

\section{PARAMYXOVIRIDAE}

The porpoise and dolphin morbilliviruses (PMV and DMV) are newly recognized members of the genus Morbillivirus (family Paramyxoviridae) which were isolated from harbour porpoises from northern Europe and striped dolphins from the Mediterranean, respectively (McCullough et al. 1991, Van Bressem et al. 1991, Visser et al. 1993). PMV and DMV are antigenically and genetically very similar and probably represent different strains of the same virus species (Barrett et al. 1993) for which the name 'cetacean morbillivirus' has been suggested (Blixenkrone-Møller et al. 1996). They are more closely related to the ruminant morbilliviruses and measles virus than to the distemper viruses (Barrett et al. 1993, Visser et al. 1993, Blixenkrone-Møller et al. 1994, 1996, Bolt et al. 1994). Molecular and antigenic data suggest that DMV is closest to the putative morbillivirus ancestor (BlixenkroneMøller et al. 1994, 1996), implying that it may be the 'archevirus' of the genus and may have infected cetaceans for hundreds of thousands or even millions of years. The wide geographic and species distribution of cetacean morbillivirus, the occurrence of potentially very large numbers of hosts among cetacean species from polar waters to tropical seas for some 2 to 5 million years (Barnes et al. 1985) and the gregarious behaviour and migratory habits of many whales and dolphins, also argue in favor of this hypothesis.

DMV-infected striped dolphins stranded on Mediterranean shores dead or moribund, while others showed signs of disorientation, such as colliding with boats. Most specimens were in poor body condition and several had ulcerative stomatitis (Domingo et al. 1992, Duignan et al. 1992). Weak sound emission as well as muscles tremors and contractions were also reported in a few striped dolphins (Piza 1991). In addition, a higher prevalence of the Balanomorpha Xenobalanus globicipitis, mainly composed of young individuals, was observed among affected dolphins, suggesting a period of debilitation and reduced swimming speed
(Aznar et al. 1994). The predominant lesions in the harbour porpoises and striped dolphins infected by either DMV or PMV were bronchiolointerstitial pneumonia and interstitial pneumonia, non-suppurative encephalitis and lymphoid depletion in the lymph nodes and spleen (Kennedy et al. 1991, Domingo et al. 1992, Duignan et al. 1992). Pneumonia and lymphoid depletion in the lymph nodes, spleen and gut-associated lymphoid tissue were also commonly observed in bottlenose dolphins Tursiops truncatus that died during a morbillivirus epizootic in 1987-1988 (Schulman et al. 1997). A detailed review of the clinical signs, gross pathology and histopathology of morbillivirus infection in cetaceans is given by Kennedy (1998). Transmission probably occurs through the inhalation of aerosolized virus, shed by infected individuals, as in other morbilliviruses (Black 1991) and is likely favored by a gregarious behaviour.

Cetacean morbillivirus (CeMV) has infected several species of odontocetes from the North Atlantic and South Pacific Oceans as well as from the Mediterranean and Black Seas (Domingo et al. 1990, Van Bressem et al. 1993a, 1998a, b, Lipscomb et al. 1994a,b, Duignan et al. 1995a,b, Birkun et al. 1998, Reidarson et al. 1998). It is probably enzootic in short- and longfinned pilot whales (Globicephala macrorhynchus and G. melas) from the North Atlantic (Duignan et al. 1995a, Van Bressem et al. 1998a) as well as in dusky dolphins Lagenorhynchus obscurus, offshore bottlenose dolphins and long- and short-beaked common dolphins Delphinus capensis and $D$. delphis from the South Pacific (Reiderson et al. 1998, Van Bressem et al. 1998b). CeMV caused epizootics in bottlenose dolphins along the Atlantic USA coast in 1982, 1987-1988 and 1993-1994 (Lipscomb et al. 1994a, Krafft et al. 1995, Duignan et al. 1996), in Mediterranean striped dolphins in 1990-1992 (Domingo et al. 1990, Van Bressem et al. 1991, 1993a, Aguilar \& Raga 1993) and possibly in short-beaked common dolphins Delphinus delphis ponticus from the Black Sea in 1994 (Birkun et al. 1998), It also likely caused the death of several harbour porpoises and a white-beaked dolphin Lagenorhynchus albirostris stranded along the coasts of northern Europe in 1988-1990 (Kennedy et al. 1988, 1991, 1992a, Visser et al. 1993, Osterhaus et al. 1995).

Mortalities were massive during the epizootics. Over $50 \%$ of the inshore bottlenose dolphins off New Jersey and south to Canaveral National Seashore', Florida, USA, may have died during the 1987-1988 epizootic (Lipscomb et al. 1994a). Although no precise mortality rates could be estimated for the Mediterranean striped

\footnotetext{
'The most southerly location from where a morbillivirus positive dolphin was diagnosed ( $T$ Lipscomb pers. comm. to M.F.B., 4 March 1.997)
} 


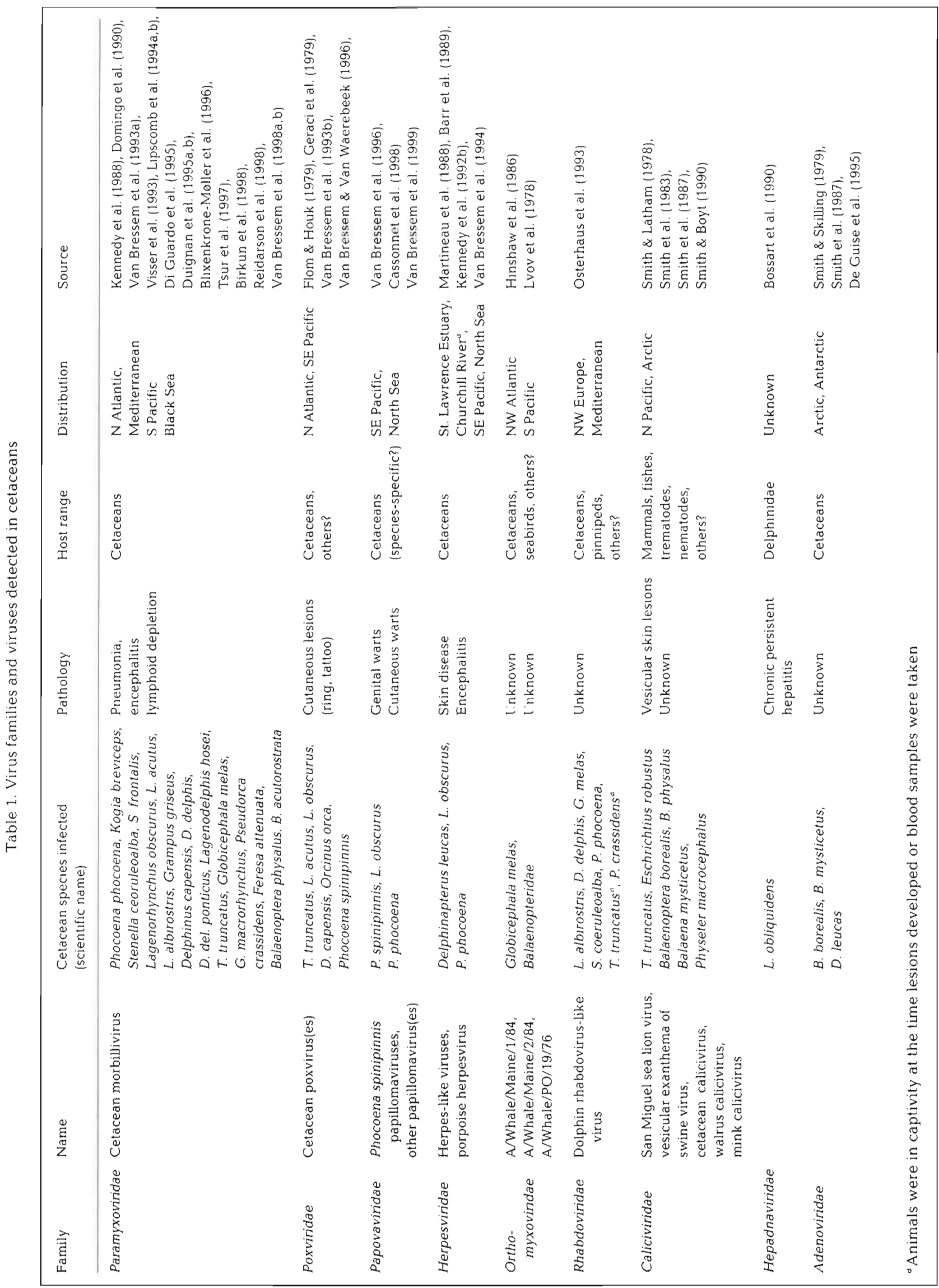


dolphin die-off of 1990-1992, probably thousands of animals perished (Aguilar \& Raga 1993, Forcada et al. 1994). As a relative measure of the impact, the mean school size in the epizootic's core regions significantly decreased to less than $30 \%$ of the pre-outbreak number (Aguilar \& Raga 1993, Forcada et al. 1994).

The high death rate, the persistence of CeMV in several populations and the natural history of other members of this genus (see Plowright 1982, May 1986, Black 1991) indicate that CeMV may have long-term effects on the dynamics of cetacean populations either as enzootic infections or recurrent epizootics. When enzootic, herd immunity exists and the disease mostly strikes newborns and calves without protective immunity (see Nathanson 1990, Griffin \& Bellini 1996). When persisting as recurrent epizootics, different age classes are affected, and the prevalence of the disease varies according to the number of susceptible animals, which in turn depends on the population size and growth rate, duration of specific immunity (lifelong in the case of other morbilliviruses) and elapsed time between successive outbreaks (see Anderson \& May 1979, Black 1991, Begon et al. 1996). As the rates of increase of the size of dolphin populations appear to be more sensitive to the noncalf survival rate than to the calf survival rate (Reilly \& Barlow 1986), recurrent epizootics probably have a more profound impact on population dynamics than enzootic infections. Harwood \& Hall (1990) reached the same conclusion for repeated mass mortalities in marine mammals.

No unusual massive, non-fisheries related mortalities of striped dolphins have been detected in the Mediterranean since 1992 (J. A. Raga unpubl. data, G. Notarbartolo di Sciara \& J. M. Bompar pers. comm. to M.F.B., 26 April and 8 May 1998). This suggests that either the virus has become enzootic in the population or that it has disappeared from it. Generally, morbilliviruses require large populations of susceptible individuals (e.g. 300000 for measles virus in humans; Black 1991) to persist enzootically since there is no carrier state and infection confers lifelong immunity. However, as several gregarious species may contribute to the persistence of CeMV in an ocean province (Van Bressem et al. 1998b), the enzootic abundance threshold for each is likely lower than the equivalent value for morbilliviruses maintained by a single mammal species, as in the case of measles virus. Thus, although the estimated number of striped dolphins in the western Mediterranean $\mathrm{Sea}^{2}$ (117880, CI $=68379-14800$; Forcada et al. 1994) could be too low to support

${ }^{2}$ There is no abundance estimate available for striped dolphins in the eastern Mediterranean at the time of writing, but it seems to be lower than in the western part (Evans 1987) endemic infection, their occasional association with other cetaceans including the short-beaked common dolphin (Forcada et al. 1994), Risso's dolphin Grampus griseus (Notarbartolo di Sciara et al. 1993), the longfinned pilot whale (R. Sagarminaga \& A. Canadas pers. comm. to J.A.R., 3 March 1997) and fin whale Balaenoptera physalus (Notarbartolo di Sciara et al. 1993) likely enhances the chances of the virus to remain enzootic. Interestingly, a high titer of morbillivirus antibodies was found in a common dolphin stranded in Sardinia at the beginning of the epizootic (Van Bressem et al. 1993a). If CeMV is not maintained in the Mediterranean, there is a risk of a new epizootic occurring due to contact with CeMV-infected cetaceans from the North Atlantic, once a new generation of susceptible individuals emerges. It is worthwhile stressing that long-finned pilot whales in the NE Atlantic were suggested to be a source of morbillivirus infection for other species of this ocean province as well as the Mediterranean, and the vector of the infection to striped dolphins in 1990 (Van Bressem et al. 1998a).

Other populations likely to have suffered long-term consequences of morbillivirus infection are short- and long-finned pilot whales in the North Atlantic (Duignan et al. 1995b, Van Bressem et al. 1998a), and dusky dolphins, offshore bottlenose and long-beaked common dolphins in the SE Pacific (Van Bressem et al. $1998 b)$. In these populations the virus is possibly enzootic and therefore may cause mortalities among young individuals.

The long-term impact of morbillivirus infection on the inshore bottlenose dolphins from the NW Atlantic and the Gulf of Mexico is more difficult to evaluate as it is unclear whether these dolphins do or do not belong to the same population (B. Taylor pers. commn. to K.V.W., 2 November 1998). However, the 1982, 1987-1988 and 1993-1994 epizootics each time struck dolphins from different areas (Lipscomb et al. 1994a, Krafft et al. 1995, Duignan et al. 1996, N. Barros \& D. Odell pers. comm. to K.V.W., 3-4 March 1997) and may be better qualified as 'progressive' than as 'recurrent' epizootics (Duignan et al. 1996).

Recent serological data indicate that immature harbour porpoises and common dolphins from the NE Atlantic that died after 1990 did not have antibodies against CeMV, suggesting that the virus is not maintained in these 'populations' (Van Bressem et al. 1998a). Reintroduction of the virus could result in new mortalities.

\section{POXVIRIDAE}

Unclassified poxviruses (family Poxviridae) were detected by electron microscopy (EM) in 'tattoo' and 
'ring' skin lesions from free-ranging bottlenose dolphins, an Atlantic white-sided dolphin Lagenorhynchus acutus, a killer whale Orcinus orca, dusky dolphins, long-beaked common dolphins and Burmeister's porpoises Phocoena spinipinnis (Flom \& Houk 1979, Geraci et al. 1979, Van Bressem et al. 1993b, Van Bressem \& Van Waerebeek 1996, R. Lewis pers. comm. to M.F.B., 17 February 1998). Serological studies in Peruvian small cetaceans have suggested that these viruses share antigens with cowpox virus, a member of the Orthopoxvirus genus (Van Bressem et al. $1998 \mathrm{c}$ ).

Ring lesions are flat or slightly raised and consist of solitary or coalesced 0.5 to $3 \mathrm{~cm}$ round or elliptical blemishes which may have a dark gray border (Geraci et al. 1979). Tattoos are irregular, slightly in relief, gray, black or yellowish lesions which may be localized or generalized (Fig. 1) (Flom \& Houk 1979, Geraci et al. 1979, Van Bressem \& Van Waerebeek 1996). Histologically, ring lesions are characterized by cytoplasmic vacuolation, the presence of intracytoplasmic inclusions in cells of the stratum intermedium and a downward thickening of the stratum externum (Geraci et al. 1979). Poxvirus infection generally does not affect the general health though severe cases may occur (Sweeney \& Ridgway 1975, Geraci et al. 1979, Van Bressem \& Van Waerebeek 1996).

Cetacean poxvirus infection has so far been encountered in odontocetes from the North Atlantic and the eastern Pacific (Flom \& Houk 1979, Geraci et al. 1979, Van Bressem et al. 1993b, Van Bressem \& Van Waerebeek 1996, Gaspar \& Van Bressem 1998; Table 1). In addition, we recognized characteristic tattoo marks in published photos of a short-beaked common dolphin from northern California (see Leatherwood et al. 1982 , p. 164) and a Mediterranean striped dolphin (Arvy

Fig. 1. (a) Tattoo lesions in a dusky dolphin Lagenorhynchus obscurus (MFB-399) from Peru. (b) Tattoo lesions in a Burmeister's porpoise Phocoena spinipinnis (MFB475) from Peru

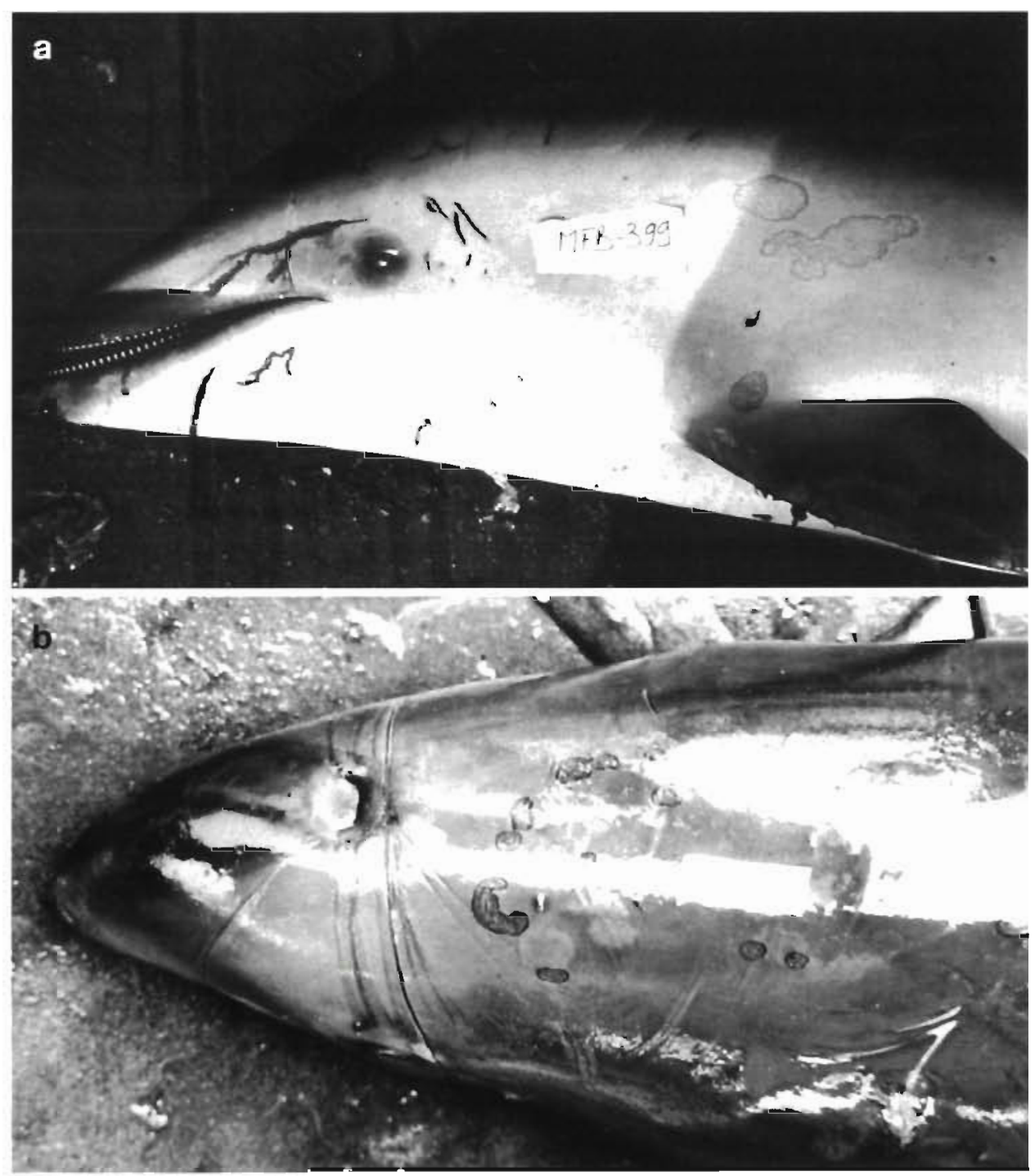


1982, p. 259). Baker (1992) and Baker \& Martin (1992) reported poxvirus infection from several NE Atlantic odontocetes but unfortunately did not publish any photos of the lesions or virus particles to support their case.

The epidemiology of poxviruses in cetaceans is largely unknown but their maintenance in communities and populations is probably favoured by a long period of infectivity as suggested by the size of the lesions and the presence of virus particles in most samples examined (Van Bressem 1997). Poxvirus infection is likely enzootic and equivalent to a children's disease in the long-beaked common dolphin, dusky dolphin, bottlenose dolphin and Burmeister's porpoise from Peruvian waters. The highest prevalence of tattoos was found in juveniles (Delphinidae) while they were absent in neonates and young calves (dusky dolphins and Burmeister's porpoises) probably because protected by maternal immunity (Van Bressem \& Van Waerebeek 1996).

Clinical and epidemiological data do not indicate that poxvirus infection induces a high mortality rate (Sweeney \& Ridgway 1975, Geraci et al. 1979, Van Bressem et al. 1993b). However, it is possible that the infection may kill neonates and calves without protective immunity and hence affects host population dynamics. Indeed, although more than one-third of inferred sexually mature female dusky dolphins (36.2\%, Van Bressem \& Van Waerebeek unpubl. data) and Burmeister's porpoises (35.7\%; Van Bressem \& Van Waerebeek 1996) suffered tattoo lesions in the period 1993-1994, indicating that a certain percentage of these females (and thus their calves) were not immune against the virus, none of the calves and neonates examined showed skin lesions (Van Bressem \& Van Waerebeek 1996).

\section{PAPOVAVIRIDAE}

Immunohistochemistry and molecular studies have recently demonstrated that papillomaviruses (family Papovaviridae, subfamily Papillomavirinae) are the etiological agents of genital tumours in Burmeister's porpoises and dusky dolphins from Peru as well as of cutaneous warts in a harbour porpoise of the North Sea (Cassonnet et al. 1998, Van Bressem et al. 1999; Table 1). In addition, macroscopic and microscopic features of genital warts of sperm whales Physeter macrocephalus from Icelandic waters and of bottlenose and long-beaked common dolphins from Peru have suggested papillomaviruses (PVs) are the etiological agents of these lesions (Lambertsen et al. 1987, Van Bressem et al. 1996)

The genital warts in the Burmeister's porpoise and dusky dolphin were observed on the skin bordering the genital slit, and on the mucosae inside the genital slit, on the penis (Fig. 2) and on the vagina (Van Bressem et al. 1996). Histologically, the lesions were characterized by hyperplasia of the stratum spinosum and koilocytosis (large perinuclear cavitation with irregular edges surrounded by a dense cytoplasm) (Van Bressem et al. 1996). In the harbour porpoise the cutaneous warts were scattered on the left side (Fig. 3), belly and on the dorsal portion of the tail fluke (Van Bressem et al. 1999). The main histological features of one of these lesions included elongated dermal papillae, a marked epidermal hyperplasia and an abnormal terminal cell differentiation (Van Bressem et al. 1999).

The genital location of the warts and their high prevalence suggested that the disease is venereally transmitted in the Burmeister's porpoise and the dusky dolphin (Van Bressem et al. 1996). The high rate of sexual activity and its central role in play and social ordering of schools among many small cetaceans including the dusky dolphin (Brown et al. 1966, Würsig \& Würsig 1978, Norris \& Dohl 1980, Wells et al. 1987 , Morris \& Lockyer 1988) may favour the maintenance of the virus in these dolphin and porpoise populations (Van Bressem 1997). As 2 of 20 male (10\%) Burmeister's porpoises suffered genital lesions of sufficient severity that may impede, or at least, hamper copulation (Van Bressem et al. 1996, Van Bressem 1997), we believe PVs (especially if non-randomly distributed) may exert an indirect impact on the dynamics of this population

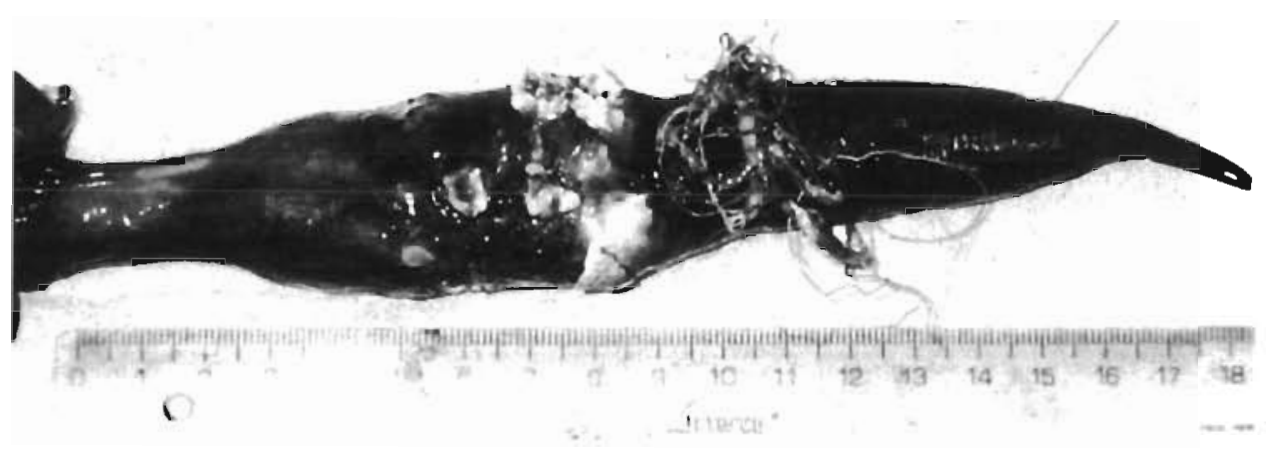

Fig. 2. Genital warts on the penis of a Burmeister's porpoise Phocoena spinipinnis (MFB-495) from Peru with seaweed lodged between the penis and its sheath 
Fig. 3. Cutaneous warts (arrows) on the side and belly of a harbour porpoise Phocoena phocoena stranded in Germany

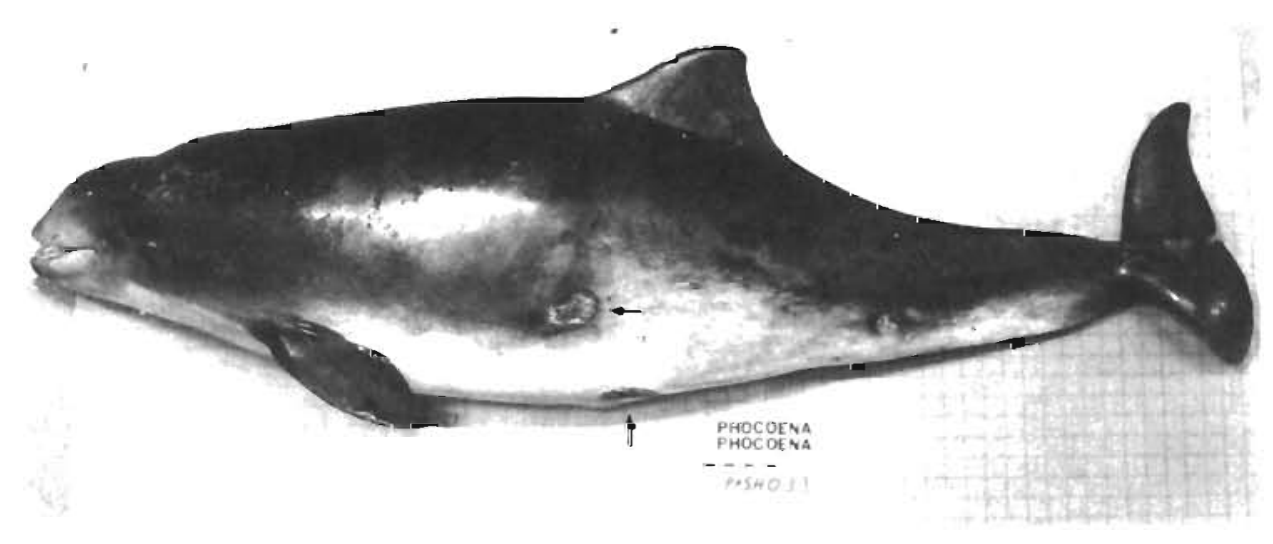

\section{HERPESVIRIDAE}

Herpesviruses and herpes-like viruses have been detected in Phocoenidae, Monodontidae and Delphinidae. A herpesvirus antigenically related to pseudorabies virus, human herpesvirus 1 and bovine herpesvirus 1 (subfamily Alphaherpesvirinae) was demonstrated by immunohistochemistry and electron microscopy in cerebral cortical neurons of a female harbour porpoise found dead on the west coast of Sweden in 1988 (Kennedy et al. 1992b). Herpes-like virus particles were observed by EM in epithelial cells from skin lesions of free-ranging and captive beluga whales Delphinapterus leucas from the St. Lawrence estuary and the Churchill river, respectively (Martineau et al. 1988, Barr et al. 1989) and of 2 dusky dolphins caught off Peru (Fig. 4) (Van Bressem et al. 1994).

The harbour porpoise was lean, suffered encephalitis, and had several other pathologies which could not be linked to the herpesvirus infection (Kennedy et al. 1992b). Microscopically, the encephalitis was characterized by the presence in the cerebral cortex of large, acidophilic intranuclear inclusions in neurons, necrotic neurons and a mild diffuse microgliosis (Kennedy et al. $1992 b)$. The skin lesions in the belugas were paler than the normal skin, were circular or elliptical and slightly in relief (Martineau et al. 1988, Barr et al. 1989). In the St. Lawrence estuary individual the marks showed a dark small center surrounded by a narrow ill-defined dark rim (Martineau et al. 1988). They were either numerous, generalized and up to $2 \mathrm{~cm}$ in diameter (St. Lawrence beluga), or few, localized and up to $20-30 \mathrm{~cm}$ in diameter (Churchill river's individual). The infection did not seem to have affected the general body condition of the captive beluga (Barr et al. 1989). Histologically, the lesions were characterized by epithelial necrosis and intranuclear inclusions. Intracellular oedema with microvesicle formation in superficial epithelium was also observed in the captive beluga (Martineau et al. 1988, Barr et al. 1989). In the dusky dolphins, black dots, perceptible by the touch, were present on the beak. The infection did not seem to be more than mildly pathogenic (Van Bressem et al. 1994).
Fig. 4. Herpesvirus-like skin lesions in a dusky dolphin Lagenorhynchus obscurus caught off central Peru

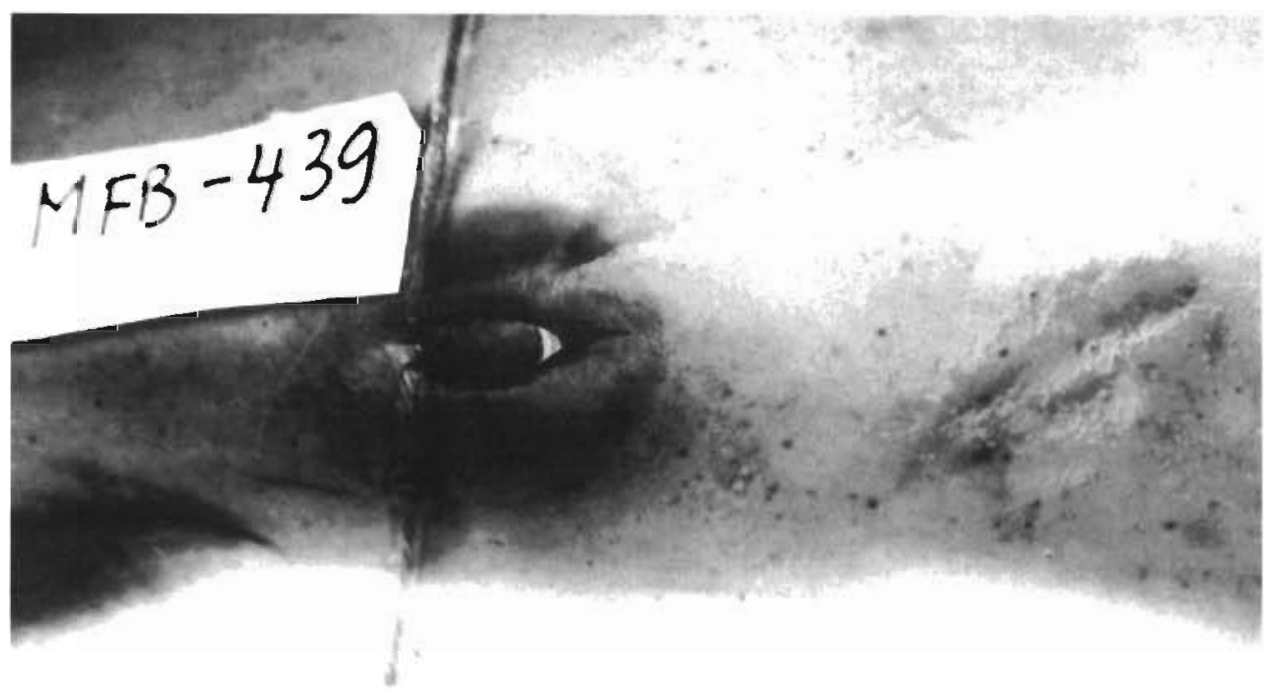


A second beluga from the St. Lawrence estuary and 2 other Peruvian dusky dolphins showed skin marks similar to those previously described but herpesvirus particles could not be detected in these animals (Martineau et al. 1988, Van Bressem et al. 1994). Herpesvirus-like skin lesions were seen on several belugas captured and released in the Churchill River in 1984 (Barr et al. 1989) and were commonly encountered in dusky dolphins (Fig. 4) landed in Peruvian fishing ports in 1993-1994 (M.-F. Van Bressem, K. Ontón, J. Alfaro-Shigueto \& K. Van Waerebeek unpubl. data). Finally, serum antibodies against a virus closely related to bovine herpes virus 1 were detected by a virus neutralization (VN) test in 6 of 13 belugas found dead along the shores of the St. Lawrence Estuary between 1995 and 1997, suggesting that exposure to a virus of the subfamily Alphaherpesvirinae occurred in this population (Mikaelian et al. 1999). After infection herpesviruses become latent and are excreted periodically or continuously during the host's entire lifetime (Roizman et al. 1995).

\section{ORTHOMYXOVIRIDAE}

Two influenza A viruses, A/whale/Maine/1/84 (H13N9) and A/whale/Maine/2/84 (H13N2) were isolated from the lung and hilar node of a sick long-finned pilot whale caught off the coast of Maine, USA, in October 1984 (Hinshaw et al. 1986, J. Geraci pers. comm. to M.F.B., 26 June 1998). A third strain of influenza $A$ virus designated A/whale/ $\mathrm{PO} / 19 / 76$ (H1N3) was isolated from the lungs and liver of unspecified rorquals (Balaenopteridae) caught in the South Pacific in 1975-1976 (Lvov et al. 1978, Murphy \& Webster 1996). The pilot whale was extremely emaciated and swam with difficulty. Necropsy revealed hemorrhagic lungs, a small and friable liver and a greatly enlarged hilar node (Hinshaw et al. 1986). Lvov et al. (1978) did not report any lesion for the infected rorquals.

The antigenic, genetic and biological properties indicated that the pilot whale and the rorqual viruses are closely related to influenza A viruses isolated from gulls Larus sp. and an unidentified tern from the Caspian sea, respectively, yet are different from known seal influenza viruses also of avian origin (Hinshaw et al. 1986, Mandler et al. 1990, Callan et al. 1995). Avian influenza $A$ viruses are the ultimate source of influenza A viruses of mammals and the largest number of these viruses has been isolated from domestic avian species and feral aquatic birds including shearwaters, terns and gulls (Fenner et al. 1993, Murphy \& Webster 1996). Associations beween seabirds and cetaceans are very common and, in the
North Atlantic, some species like the minke whale Balaenoptera acutorostrata and the long-finned pilot whale are found associated with more bird species (including shearwaters and gulls) and more regularly than others (Evans 1982). Such a behaviour could favour virus transmission.

\section{RHABDOVIRIDAE}

Osterhaus et al. (1993) isolated a rhabdo-like virus from the lungs and kidneys of a white-beaked dolphin which stranded alive on the Dutch coast in the spring of 1992 and died after 2 d of intensive care with signs of severe dyspnea. Neutralization and immunofluorescence tests showed that the virus is antigenically different from members of the 3 recognized genera of animal rhabdoviruses, i.e. rabies virus (genus Lyssavirus), bovine ephemeral fever virus (genus Ephemerovirus) and vesicular stomatitis virus (genus Vesiculovirus).

Subsequently, this team found neutralizing antibodies to the 'dolphin rhabdovirus-like virus' (DRV) in striped dolphins, common dolphins, long-finned pilot whales, white-beaked dolphins and harbour porpoises stranded on the coasts of Northwestern Europe and the Mediterranean Sea (precise origin for individuals not given) in 1988-1992, as well as in presumably captive false killer whales Pseudorca crassidens and bottlenose dolphins. VN antibodies were also detected in a harbour seal Phoca vitulina and grey seals Halichoerus grypus sampled in NW Europe during the same period (Osterhaus et al. 1993). It is noteworthy that several animal rhabdoviruses have a broad host range, extending from nearly all mammals to arthropods (Dietzchold et al. 1996). Arthropods, especially biting insects, play an important role in the life cycle of several rhabdoviruses (Shope \& Tesh 1987). The arthropods infesting cetaceans include 2 groups of crustaceans, but no insects (Raga 1994). Cyamids (Amphipoda) and pennellids (Copepoda) feed on the skin and blood of their hosts, respectively (Raga 1994).

\section{CALICIVIRIDAE}

Several caliciviruses (family Caliciviridae) have been demonstrated in cetaceans. Most are serotypes of the San Miguel sea lion virus (SMSV) and the vesicular exanthema of swine virus (VESV), which belong to the same virus species (Smith \& Boyt 1990, Fenner et al. 1993). Cetacean calicivirus (CCV Tur-1) was isolated from vesicular skin lesions which developed on a tattoo and old scars in 2 Atlantic bottlenose dolphins. The vesiculae quickly eroded, leaving shallow ulcers in one of the dolphins (Fig. 5; Smith et al. 1983). SMSV-9 
serotype, initially recovered from a California sea lion pup, was subsequently isolated from a Pacific bottlenose dolphin (Smith \& Boyt 1990).

Neutralizing antibodies to several SMSV and VESV serotypes as well as the walrus calicivirus and the mink calicivirus were detected by serology in gray whales Eschrichtius robustus, fin whales, sei whales Balaenoptera borealis and sperm whales from the North Pacific (Smith \& Latham 1978, Smith \& Boyt 1990), in bowhead whales Balaena mysticetus caught off Barrow, Alaska (Smith et al. 1987, O'Hara et al. 1998), and in bottlenose dolphins (Smith \& Boyt 1990). SMSV and VESV serotypes have a wide range of phylogenetically unrelated host species, from a liver fluke Zalophotrema sp. to marine and terrestrial mammals including humans and they may persist in their host (Smith et al. 1980a,b, 1983, Gelberg et al. 1982, Smith \& Boyt 1990). California sea lions and one of their prey, the opaleye fish Girella nigricans (Dailey 1970), may be primarily involved in the maintenance of the viruses in the North Pacific Ocean (Smith et al. 1980a, Smith \& Boyt 1990). Transmission of the virus to other marine mammals is probably linked to contacts between species, migratory pathways and vectors (Smith et al. 1980a,b, Smith \& Boyt 1990). Metazoan parasites like Zalophotrema $\mathrm{sp}$. and Parafilaroides

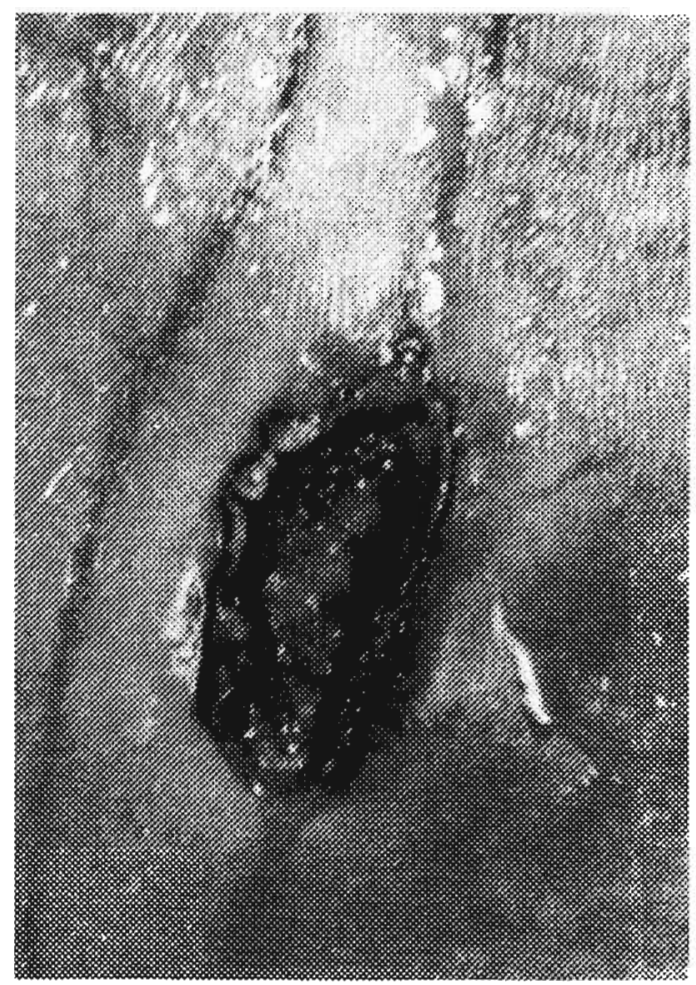

Fig. 5. Calicivirus-associated vesicular lesion in a captive bottlenose dolphin Tursiops truncatus. From Smith et al. (1983), with permission decorus may act as mechanical vectors (Smith et al. $1980 a, b)$

\section{HEPADNAVIRIDAE}

Hepatitis B virus (HBV) DNA and antibodies to the core and surface antigens of HBV were detected in the serum of a captive Pacific white-sided dolphin Lagenorhynchus obliquidens with chronic persistent hepatitis (Bossart et al. 1990). As these antigens cross-react among mammalian hepadnaviruses (Robinson 1990) and Hepadnaviridae have a restricted host range (Lanford et al. 1998), these findings strongly suggest that an unrecognized member of this family may infect Delphinidae. The dolphin had a cyclical pattern of icterus, lethargy, inappetance, skin lesions as well as of increased concentrations of serum alanine and aspartate aminotransferases (indicators of hepatocellular damage) and $\gamma$-glutamyl transferase (Bossart et al. 1990, Hollinger 1990).

Another Pacific white-sided dolphin which had shared the pool of the hepadnavirus infected dolphin had died 5 yr before of chronic-active hepatitis of unknown origin (Bossart et al. 1990). A killer whale housed in the same facility may have been infected by the virus, as it had antibodies against HBV surface antigen though not against HBV core antigen (Bossart et al. 1990). No serological evidence of hepadnavirus infection was found in 10 captive Atlantic bottlenose dolphins from the same dolfinarium (but different pools) as the infected Pacific white-sided dolphin or from other dolfinaria, nor in 2 stranded Atlantic bottlenose dolphins (Bossart et al. 1990).

\section{ADENOVIRIDAE}

Adenoviruses were isolated from rectal swabs of a sei whale taken in the Antarctic (Smith \& Skilling 1979), from colon samples of 2 bowhead whales harvested at Barrow, Alaska (Smith et al. 1987) and from the intestines of a beluga from the St. Lawrence estuary (De Guise et al. 1995). The relationships between the 4 cetacean isolates have not been investigated. The bowhead whale isolates were not neutralized by antisera to bovine adenovirus serotypes $1-8$ nor by antisera to an adenovirus isolate from gazelles and other hoofed species (Smith et al. 1987). The taxonomic status of the whale adenoviruses within the family remains to be elucidated.

No macro- or microscopic lesions were reported in the individuals from which the viruses were isolated and they probably did not cause serious diseases. In other mammals adenoviruses cause mild or subclinical 
gastroenteric diseases among other symptoms (Fenner et al. 1993, Horwitz 1996). All infections with adenoviruses are associated with long periods of latency and adenoviruses can be recovered from apparently healthy animals (Fenner et al. 1993).

\section{OTHER VIRUSES}

Viruses were isolated from rectal swabs from 2 California gray whales caught by whalers (Watkins et al. 1969). They were classified as analogous to echoviruses (family Picornaviridae) on the basis of their physical properties but were not neutralized by antisera to several echoviruses (Watkins et al. 1969). Without further information on these isolates we consider their classification as tentative.

\section{CONCLUSIONS}

Until now viruses of at least 9 families have been detected in cetaceans. Some of these (cetacean morbillivirus and a 'porpoise herpesvirus') cause serious lethal diseases while the health consequences of infections by influenza-, rhabdo-, and adeno-viruses remain unknown. Infection by an unrecognized hepadnavirus was associated with chronic persistent hepatitis. Viruses of the families Poxviridae, Papovaviridae, Herpesviridae and Caliciviridae cause epithelial lesions of the skin and/or genital tract.

Some viruses appear to be species- (e.g. papillomaviruses) or order- (e.g. morbillivirus) specific, while others (influenza-, rhabdo- and caliciviruses) have a broader host range including animals from different classes and/or phyla. Many factors, including the infectiousness, duration of infectiousness and immunity, lifespan of infective stage and pathogenicity (see Anderson \& May 1979), but also host range, host biology and population characteristics (e.g. rate of increase) will co-determine whether each of these viruses persist and their degree of maintenance.

Extrinsic anthropogenic factors including fisheries interactions, pollution and habitat loss and degradation (see Reeves \& Leatherwood 1994) possibly may not only exacerbate the consequences of viral infections on the health of a particular individual, but also operate at the population level. By reducing the number of animals in a population, and hence the number of susceptible individuals, fisheries may prevent the establishment of enzootic morbillivirus infections and favour recurrent epizootics which will further deplete the population (Van Bressem 1997). The contributing role of pollutants in virus-induced mass mortalities in marine mammals was recently reviewed by Ross et al.
(1996). Simmonds \& Mayer (1997) have discussed the part environmental factors may have played in these mortalities

At least 3 distinct virus families (Paramyxoviridae, Poxviridae and Papovaviridae) have the potential to exert a negative impact on the population dynamics of cetaceans, by increasing natural mortality and/or by negatively affecting reproduction. In the course of time they could also have influenced the actual distribution of some cetacean stocks, as rinderpest virus did of some feral African artiodactyls (Anderson 1995). While morbilliviruses are the more conspicuous because of the massive die-offs they cause, both papillomaviruses and poxviruses deserve further attention.

We recommend to systematically include at least serological, pathological and epidemiological studies of viral diseases in all advanced biological research programmes of cetaceans, and to account for the potential impact of microparasites when constructing population dynamics models.

Acknowledgements. We kindly thank Dr C. Desaintes for logistical support, Drs D. Dekegel, J. R. Geraci, R. Kastelein, A. D. M. E. Osterhaus, A. W. Smith and Dolfinarium Harderwijk, for providing unpublished information and/or some of the photographs used in this article, and Dr P.-P. Pastoret for his comments on the manuscript. CEPEC research was partially funded by the Gesellschaft zum Schutz der Meeressäugetiere, Marine Education and Research and Idea Wild. M.F.B. received support from the Belgian Agency for Development Aid (AGCD). Data collection on Peruvian cetaceans by K.V.W. has been supported by the Leopold III Fund for Nature Research and Conservation for many years.

\section{LITERATURE CITED}

Aguilar A, Raga JA (1993) The striped dolphin epizootic in the Mediterranean Sea. Ambio 22:524-528

Anderson EC (1995) Morbillivirus infections in wildlife (in relation to their population biology and disease control in domestic animals). Vet Microbiol 44:319-332

Anderson RM (ed) (1982) Population dynamics of infectious disease agents: theory and applications. Chapman and Hall, London

Anderson RM, May RM (1979) Population biology of infectious diseases: Part I. Nature 280:361-367

Arvy $L$ (1982) Phoresies and parasitism in cetaceans: a review Invest Cetacea 14:233-335

Aznar J, Balbuena JA, Raga JA (1994). Are epizoites biological indicators of a Western Mediterranean striped dolphin die-off? Dis Aquat Org 18:59-163

Baker JR (1992) Causes of mortality and parasites and incidental lesions in dolphins and whales from British waters Vet Rec 130:569-572

Baker JR, Martin AR (1992) Causes of mortality and parasites and incidental lesions in harbour porpoises (Phocoena phocoena) from British waters. Vet Rec 130:554-558

Barnes LG, Domning DP, Ray CE (1985) Status of studies on fossil marine mammals. Mar Mamm Sci 1:15-53

Barr B, Dunn JL, Daniel MD, Banford A (1989) Herpes-like viral dermatitis in a beluga whale (Delphinapterus 
leucas). J Wildl Dis 25:608-611

Barrett T, Visser IKG, Mamaev L, Goatley L, Van Bressem MF, Osterhaus ADME (1993). Dolphin and porpoise morbilliviruses are genetically distinct from phocine distemper virus. Virology 193:1010-1012

Begon M, Harper JL, Townsend CR (1996) Ecology, 3rd edn. Blackwell Science, Oxford

Birkun A, Kuiken T, Krivokhizhin S, Haines DM, Osterhaus ADME, Van de Bildt MWG, Joiris CR, Siebert U (1998) Epizootic of morbilliviral disease in common dolphins (Delphinus delphis ponticus) from the Black Sea. Vet Rec 144:85-92

Black F (1991) Epidemiology of Paramyxoviridae. In: Kingsburry DW (ed) The Paramyxoviruses. Plenum Press, New York, p 509-536

Blixenkrone-Møller M, Bolt G, Gottschalk E, Kenter M (1994) Comparative analysis of the gene encoding the nucleocapsid protein of dolphin morbillivirus reveals its distant evolutionary relationship to measles virus and ruminant morbilliviruses. J Gen Virol 75:2829-2834

Blixenkrone-Maller M, Bolt G, Jensen TD, Harder T, Svansson $V$ (1996) Comparative analysis of the attachment protein gene $(\mathrm{H})$ of dolphin morbillivirus. Virus Res 40:47-56

Bolt G, Blixenkrone-Moller M, Gottschalk E, Wishaupt RGA, Welsh MJ, Earle PJA, Rima BK (1994) Nucleotide and deduced amino acid sequences of the matrix (M) and fusion (F) protein genes of cetacean morbilliviruses isolated from a porpoise and a dolphin. Virus Res 34:291-304

Bossart GD, Brawner TA, Cabal C, Kuhns M, Eimstad EA, Caron J, Trimm M, Bradley P (1990) Hepatitis B-like infection in a Pacific white-sided dolphin (Lagenorhynchus obliquidens). JAVMA 196:127-130

Brown DH, Caldwell DK, Caldwell MC (1966) Observations on the behavior of wild and captive false killer whales, with notes on associated behavior of other genera of captive delphinids. Contri Sci 95:1-32

Callan RJ, Early G, Kida H, Hinshaw VS (1995) The appearance of $\mathrm{H} 3$ influenza viruses in seals. J Gen Virol 6: $199-203$

Cassonnet P, Van Bressem MF, Desaintes C, Van Waerebeek K, Orth G (1998) Papillomaviruses cause genital warts in small cetaceans from Peru. The World Marine Mammal Science Conference, Monaco, January 1998 (abstract)

Dailey MD (1970) The transmission of Parafilaroides decorus (Nematoda: Metastrongyloidea) in the California sea lion (Zalophus californianus). Proc Helminthol Soc Wash 37 : 215-222

De Guise S, Lagace A, Beland P, Girard C, Higgins R (1995) Non-neoplastic lesions in beluga whales (Delphinapterus leucas) and other marine mammals from the St. Lawrence Estuary. J Comp Pathol 112:257-271

Dietzchold B, Rupprecht CE, Fang Fu Z, Koprowsky H (1996) Rhabdoviruses. In: Fields BN, Knipe DM, Howley PM, Chanock RM, Melnick JI, Monath TP, Roizman B, Straus SE (eds) Fields Virology, 3rd edn. Lippincott-Raven Publishers, Philadelphia, p 1137-1159

Di Guardo G, Agrimi U, Morelli L, Cardeti G, Terracciano G, Kennedy S (1995) Post mortem investigations on cetaceans found stranded on the coasts of Italy between 1990 and 1993. Vet Rec 136:439-442

Domingo M, Ferrer L, Pumarola $M$, Marco A, Plana J, Kennedy S, McAliskey M, Rima BK (1990) Morbillivirus in dolphins. Nature 348:21

Domingo M, Visa J, Pumarola M, Marco AJ, Ferrer L, Rabanal R, Kennedy S (1992) Pathologic and immunocytochemical studies of morbillivirus infection in striped dolphins (Stenella coeruleoalba). Vet Pathol 29:1-10
Duignan PJ, Geraci JR, Raga JA, Calzada N (1992) Pathology of morbillivirus infection in striped dolphins (Stenella coeruleoalba) from Valencia and Murcia, Spain. Can J Vet Res 56:242-248

Duignan PJ, House C, Geraci JR, Early G, Copland HG, Walsh MT, Bossart GD, Cray C. Sadove S, St. Aubin DJ, Moore NI (1995a) Morbillivirus infection in two species of pilot whales from the western Atlantic. Mar Mamm Sci 11:150-162

Duignan PJ, House C, Geraci JR, Duffy N, Rima BK, Walsh MT, Early G, St. Aubin DJ, Sadove S, Koopman H, Rhinehart $\mathrm{H}$ (1995b) Morbillivirus infection in cetaceans of the western Atlantic. Vet Microbiol 44:41-249

Duignan PJ, House C, Odell DK, Wells RS, Hansen LJ, Walsh MT, St. Aubin DJ, Rima BK, Geraci JR (1996) Morbillivirus in bottlenose dolphins: evidence for recurrent epizootics in the western Atlantic and Gulf of Mexico. Mar Mamm Sci 12:499-515

Evans PGH (1982) Associations between seabirds and cetaceans: a review. Mammal Rev 12:187-206

Evans PGH (ed) (1987) The natural history of whales and dolphins. Christopher Helm, Kent

Fenner F (1983) The Florey Lecture, 1983: biological control, as exemplified by smallpox eradication and myxomatosis. Proc R Soc Lond B 218:259-285

Fenner FJ, Gibbs EPG, Murphy FA, Rott R, Studdert MJ, White DO (1993) Veterinary virology, 2nd edn. Academic Press Inc, San Diego, California

Flom JO, Houk EJ (1979) Morphologic evidence of poxvirus in 'tattoo' lesions from captive bottlenosed dolphins. J Wildl Dis 15:593-596

Forcada J, Aguilar A, Hammond PS, Pastor X, Aguilar R (1994) Distribution and numbers of striped dolphins in the western Mediterranean sea after the 1990 epizootic outbreak. Mar Mamm. Sci 10:137-150

Gaspar R, Van Bressem MF (1998) Poxvirus infection in bottlenose dolphins from the Sado Estuary, Portugal. The World Marine Mammal Science Conference, Monaco, January 1998 (abstract)

Gelberg HB, Dieterich RA, Lewis RM (1982) Vesicular exanthema of swine and San Miguel sea lion virus: experimental and field studies in otarid seals, feeding trials in swine. Vet Pathol 19:413-423

Geraci JR, Hicks BD, St. Aubin DJ (1979) Dolphin pox: a skin disease of cetaceans. Can J Comp Med 43:399-404

Griffin DE, Bellini WJ (1996) Measles virus. In: Fields BN, Knipe DM, Howley PM, Chanock RM, Melnick JI, Monath TP, Roizman B, Straus SE (eds) Fields virology, 3rd edn. Lippincott-Raven Publishers, Philadelphia, p 1267-1312

Gulland F (1995) The impact of infectious diseases on wild animal populations - a review. In: Grenfeld BT, Dobson AP (eds) Ecology of infectious diseases in natural populations. Cambridge University Press, Cambridge, p 20-51

Harwood J, Hall A (1990) Mass mortality in marine mammals: its implications for population dynamics and genetics. TREE 5:254-257

Hinshaw VS, Bean WJ, Geraci J, Fiorelli P, Early G, Webster RG (1986) Characterization of two influenza A viruses from a pilot whale. J Virol 58:655-656

Hollinger FB (1990) Hepatitis B virus. In: Fields BN, Knipe DM (eds) Virology, 2nd edn. Raven Press, New York, p $2171-2236$

Horwitz MS (1996) Adenoviruses. In: Fields BN, Knipe DM. Howley PM, Chanock RM, Melnick JI, Monath TP, Roizman B, Straus SE (eds) Fields virology, 3rd edn. Lippincott-Raven Publishers, Philadelphia, p 2149-2171

Kennedy S (1998) Morbillivirus infections in aquatic mammals. J Comp Path 119:201-225 
Kennedy S, Smyth JA, Cush PF, McCullough SJ, Allan GM, McQuaid S (1988) Viral distemper now tound in porpoises. Nature 336:21

Kennedy S, Smyth JA, Cush PF, McAliskey M, McCullough SJ, Rima BK (1991) Histopathologic and immunocytochemical studies of distemper in harbour porpoises. Vet Pathol 28:1-7

Kennedy $S$, Kuiken $T$, Ross HM, McAliskey $M$, Moffett D, McNiven CM, Carole M (1992a) Morbillivirus infection in two common porpoises (Phocoena phocoena) from the coasts of England and Scotland. Vet Rec 131:286-290

Kennedy S, Lindstedt IJ, Mc Aliskey MM, McConnell SA, McCullough SJ (1992b) Herpesviral encephalitis in a harbor porpoise (Phocoena phocoena). J Zoo Wildl Med 23: $374-379$

Krafft A, Lichy JH, Lipscomb TP, Klaunberg BA, Kennedy S, Taunbenberger JK (1995) Postmortem diagnosis of morbillivirus infection in bottlenose dolphins (Tursiops truncatus) in the Atlantic and Gulf of Mexico epizootics by polymerase chain reaction-based assay. J Wildl Dis 31:410-415

Lambertsen RH, Kohn BA, Sundberg JP, Buergelt CD (1987) Genital papillomatosis in sperm whale bulls. J Wildl Dis $23: 361-367$

Lanford RE, Chavez D, Brasky KM, Burns RB, Rico-Hesse R (1998) Isolation of a hepadnavirus from the woolly monkey, a New World primate. Proc Natl Acad Sci USA 95 $5757-5761$

Leatherwood S, Reeves RR, Perrin WF, Evans EW (1982) Whales, dolphins, and porpoises of the eastern North Pacific and adjacent Arctic waters. A guide to their identification. NOAA Technical Report NMFS Circular 444 Department of Commerce, USA

Lipscomb TP, Schulman FY, Moffett D, Kennedy S (1994a) Morbilliviral disease in Atlantic bottlenose dolphins (Tursiops truncatus) from the 1987-1988 epizootic. J Wildl Dis $30: 567-571$

Lipscomb TP, Kennedy S, Moffett D, Ford DK (1994b) Morbilliviral disease in an Atlantic bottlenose dolphin (Tursiops truncatus) from the Gulf of Mexico. J Wildl Dis 30:572-576

Lvov DK, Zdanov VM, Sazonov AA, Braude NA, Vlađimirtceva EA, Agafonova LV, Skljanskaja EI, Kaverin NV Reznik VI, Pysina TV, Oserovic AM, Berzin AA, Mjasnikova IA, Podcernjaeva RY, Klimenko SM., Andrejev VP. Yakhno MA (1978) Comparison of influenza viruses isolated from man and from whales. Bull WHO 56:923-930

Mandler J, Gorman OT, Ludwig S, Schroeder E, Fitch WM, Webster RG, Scholtissek C (1990) Derivation of the nucleoproteins (NP) of influenza A viruses isolated from marine mammals. Virology 176:255-261

Martineau D, Lagacé A, Béland P, Higgins R, Armstrong D, Shugart LR (1988) Pathology of stranded beluga whales (Delphinapterus leucas) from the St. Lawrence Estuary, Québec. Can J Comp Pathol 98:287-311

May RM (1986) The cautionary tale of the black-footed ferret Nature 320:13-14

McCullough SJ, McNeilly F, Allan GM, Kennedy S, Smyth JA, Cosby SL, MCQuaid S, Rima BK (1991) Isolation and characterization of a porpoise morbillivirus. Arch Virol $118: 247-252$

Mikaelian I, Tremblay MP, Montpetil C. Tessaro SV, Cho H.J, House C, Measures L, Martineau D (1999) Seroprevalence of selected viral infections in a population of beluga whales (Delphinapterus leucas) in Canada. Vet Rec 144 $50-51$

Morris RJ, Lockyer C (1988) Twenty-two months in the life of a juvenile wild bottlenose dolphin. Aquat Mamm 14: $49-62$
Murphy BR, Webster RG (1996) Orthomyxoviruses. In: Fields BN, Knipe DM, Howley PM, Chanock RM, Melnick JI, Monath TP, Roizman B, Straus SE (eds) Fields virology, 3rd edn. Lippincott-Raven Publishers, Philadelphia, p $1397-1445$

Nathanson N (1990) Epidemiology. In: BN Fields, DM Knipe (eds) Virology, 2nd edn. Raven Press, Ltd, New York, p 267-291

Norris KS, Dohl TP (1980) The structure and function of cetacean schools. In: Herman LM (ed) Cetacean behavior: mechanisms and functions, John Wiley \& Sons, New York, p 211-261

Nortobartolo di Sciara G, Venturino MC, Zanardelli M, Bearzi G, Borsani FJ, Cavalloni B (1993) Cetaceans in the central Mediterranean Sea: distribution and sighting frequencies. Boll Zool 60:131-138

O'Hara TM, House C, House JA, Suydam RS, George JC (1998) Viral serologic survey of bowhead whales in Alaska. J Wildl Dis 34:39-46

Osterhaus ADME, Broeders HWJ, Teppema JS, Kuiken T, House JA, Vos HW, Visser IKG (1993) Isolation of virus with rhabdovirus morphology from a white-beaked dolphin (Lagenorhynchus albirostris). Arch Virol 133:189-193

Osterhaus ADME, De Swart RL, Vos HW, Ross PS, Kenter MJH, Barrett T (1995) Morbillivirus infections of aquatic mammals: newly identified members of the genus. Vet Microbiol 44:219-227

Piza J (1991) Striped dolphin mortality in the Mediterranean. In: Pastor $X$, Simmonds $M$ (eds) Proceedings of the Mediterranean Striped Dolphin Mortality International Workshop, Palma de Majorca 4-5 November 1991, p 93-103

Plowright $W$ (1982) The effects of rinderpest and rinderpest control on wildlife in Africa. Symp Zool Soc Lond 50:1-28

Raga JA (1994) Parasitismus bei Cetacea. In: Robineau D, Duguy $R$, Klima $M$ (eds) Handbuch der Säugetiere Europas, Bd 6/1A. Aula-Verlag, Wiesbaden, p 132-179

Raga JA, Balbuena JA, Aznar FJ, Fernandez M (1997) The impact of parasites on marine mammals: a review. Parassitologia 39:293-296

Reeves RR, Leatherwood S (1994) Dolphins, porpoises and whales: 1994-1998 action plan for the conservation of cetaceans. IUCN, Gland

Reidarson TH, McBain J, House C, King DP, Stott JL, Krafft A, Taubenberger JK, Heyning J, Lipscomb TP (1998) Morbillivirus infection in stranded common dolphins from the Pacific Ocean. J Wildl Dis 34:771-776

Reilly SB, Barlow J (1986) Rates of increase in dolphin popuIation size. Fish Bull 84:527-533

Robinson WS (1990) Hepadnaviridae and their replication. In: Fields BN, Knipe DM (eds) Virology, 2nd edn. Raven Press, New York, p 2137-2170

Roizman B, Desrosiers RC, Fleckenstein B, Lopez C, Minson AC, Studdert MJ (1995) Family Herpesviridae. In: Murphy FA, Fauquet CM, Bischop DHL, Ghabrial SA, Jarvis AW, Martelli GP, Mayo MA, Summers MD (eds) Virus taxonomy, Sixth Report of the International Committee on Taxonomy of Viruses. Archives of Virology Supplement 10. Springer-Verlag, New York, p 114-127

Ross P, De Swart R, Addison R, Van Loveren H, Vos J, Osterhaus ADME (1996) Contaminant-induced immunotoxicity in harbour seals: wildlife at risk? Toxicology 112:157-169

Schulman FY, Lipscomb TP, Moffett D, Krafft AE, Lichy JH. Tsai MM, Taubenberger JK, Kennedy S (1997) Histologic, immunohistochemical, and polymerase chain reaction studies of bottlenose dolphins from the 1987-88 United States Atlantic coast epizootic. Vet Pathol 34:288-295 
Shope RE, Tesh RB (1987) The ecology of rhabdoviruses that infect vertebrates. In: Wagner RR (ed) The rhabdoviruses. Plenum Press, New York, p 509-534

Simmonds MP, Mayer SJ (1997) An evaluation of environmental and other factors in some recent marine mammal mortalities in Europe: implications for conservation and management. Environ Rev 5:89-98

Smith AW, Boyt PM (1990) Calicivirus of ocean origin: a review. J Zoo Wildl Med 21:3-23

Smith AW, Latham AB (1978) Prevalence of vesicular exanthema of swine antibodies among feral mammals associated with the southern California coastal zones. Am J Vet Res 39:291-296

Smith AW, Skilling DE (1.979) Virus and virus diseases of marine mammals. JAVMA 175:918-920

Smith AW, Skilling DE, Dardiri AH, Latham AB (1980a) Calicivirus pathogenic for swine: a new serotype isolated from opaleye Girella nigricans, an ocean fish. Science 209: 940-941

Smith AW, Skilling DE, Brown RJ (1980b) Preliminary investigation of a possible lung worm (Parafilaroides decorus), fish (Girella nigricans) and marine mammal (Callorhinus ursinus) cycle for San Miguel sea lion virus type 5. Am J Vet Res 41:1846-1850

Smith AW, Skilling DE, Ridgway S (1983) Calicivirus-induced vesicular disease in cetaceans and probable interspecies transmission. JAVMA 183:1223-1225

Smith AW, Skilling DE, Bernirschke K, Albert FT, Barlough JE (1987) Serology and virology of the bowhead whale (Balaena mysticetus L.). J Wildl Dis 23:92-98

Sweeney JC, Ridgway SH (1975) Common diseases of small cetaceans. JAVMA 167:533-540

Thorne ET, Williams E (1988) Disease and endangered species: the black-footed ferret as a recent example. Conserv Biol 2:66-74

Tsur l, Goffman O, Yakobsen B, Moffet D, Kennedy S (1997) Morbillivirus infection in a bottlenose dolphin (Tursiops truncatus) from the Mediterranean Sea. Eur $J$ Vet Pathol 2:83-85

Van Bressem MF (1997) Natural history of virus infections in cetaceans. PhD thesis, University of Liège

Van Bressem MF, Van Waerebeek K (1996) Epidemiology of poxvirus in small cetaceans from the Eastern South Pacific. Mar Mamm Sci 12:371-382

Van Bressem MF, Visser IKG, Van De Bildt MWG, Teppema JS, Raga JA, Osterhaus ADME (1991) Morbillivirus infection in Mediterranean striped dolphins (Stenella coeruleoalba). Vet Rec 129:471-472

Editorial responsibility: Murray Dailey,

Sausalito, California, USA
Van Bressem MF, Visser IKG, De Swart RL, Orvell C, Stanzani L, Androukaki E, Siakavara K, Osterhaus ADME (1993a) Dolphin morbillivirus infection in different parts of the Mediterranean sea. Arch Virol 129:235-242

Van Bressem MF, Van Waerebeek K, Reyes JC, Dekegel D. Pastoret PP (1993b) Evidence of poxvirus in dusky dolphin (Lagenorhynchus obscurus) and Burmeister's porpoise (Phocoena spinipinnis) from coastal Peru. J Wildl Dis 29: $109-113$

Van Bressem MF, Van Waerebeek K, Garcia-Godos A, Dekegel D. Pastoret PP (1994) Herpes-like virus in dusky dolphins Lagenorhynchus obscurus, from coastal Peru. 1994. Mar Mamm Sci 10:354-359

Van Bressem MF, Van Waerebeek K, Piérard G, Desaintes C (1996) Genital and lingual warts in small cetaceans from. coastal Peru. Dis Aquat Org 26:1-10

Van Bressem MF, Jepson P, Barrett T (1998a) Further insight on the epidemiology of cetacean morbillivirus in the Northeastern Atlantic. Mar Mamm Sci 14:605-613

Van Bressem MF, Van Waerebeek K, Fleming M, Barrett T (1998b) Serological evidence of morbillivirus infection in small cetaceans from the Southeast Pacific. Vet Microbiol $59: 89-98$

Van Bressem MF, Van Waerebeek K, Bennett M (1998c) Cetacean poxviruses are antigenically related to cowpox virus. The World Marine Mammal Science Conference, Monaco, January 1998 (abstract)

Van Bressem MF, Kastelein RA, Flamant P, Orth G (1999) Cutaneous papillomavirus infection in a harbour porpoise (Phocoena phocoena) from the North Sea. Vet Rec 144: $592-593$

Visser IKG, Van Bressem MF, De Swart RL, van de Bildt MWG, Vos HW, Van der Heijden RWJ, Saliki JT, Örvell C, Kitching P, Kuiken T, Barrett T, Osterhaus ADME (1993) Characterization of morbilliviruses isolated from dolphins and porpoises in Europe. J Gen Virol 74:631-641

Watkins HMS, Worthington GRL, Latham AB, Leibovitz A (1969) Isolation of enterovirus from the California gray whale (Escherichtius gibbosus). Bacteriological Proceedings, American Society for Microbiology, Abstract of the 69th Annual Meeting, Miami Beach, Florida, May 1969 (abstract)

Wells RS, Scott MD, Irvine AR (1987) The social structure of free-ranging bottlenose dolphins. In: HH Genoway (ed) Current mammalogy, Vol I. Plenum Press, New York, p 247-301

Würsig B, Würsig M (1978) Day and night of the dolphin. Nat Hist 88:60-67

Submitted: April 1, 1999; Accepted: July 20, 1999

Proofs received from author(s): October 7, 1999 